\title{
WSPÓł-POWIEDZENIE... O FUNKCJI WIELOKROPKA W JĘZYKU OGÓLNYM I W POEZJI BOLESŁAWA LEŚMIANA
}

Słowa klucze: wielokropek, składnia pozycji, Bolesław Leśmian Keywords: ellipsis, position syntax, Bolesław Leśmian

Artykuł dotyczy zjawiska językowego, którego status i forma nie są łatwo uchwytne. Mam tu na myśli sytuację, w której nadawca komunikatu powierza zadanie dopowiedzenia określonej treści adresatowi. Przekazanie głosu rozmówcy sygnalizowane jest w subkodzie mówionym za pomocą intonacji otwartej, odróżniającej się przebiegiem wysokości sylab w takcie finalnym od konturu właściwego oznajmieniom i pytaniom (por. Zaucha 2015: 80-83). W wypadku subkodu pisanego wyrazem apelu o dokończenie myśli jest znak wielokropka. W dalszej części artykułu będę chciała wskazać funkcję tego ciągu graficznego w wypowiedziach nieliterackich oraz $\mathrm{w}$ utworach poetyckich Bolesława Leśmiana. Wychodzę przy tym z założenia, że w poezji rola danego elementu językowego (za taki uważam wielokropek i odpowiadający mu kontur intonacyjny) nabudowana jest na funkcji związanej z nim kodowo.

\section{Składnia poza zdaniem}

Funkcja takich środków językowych, jak wielokropek czy pauza, należy do zagadnień szeroko pojętej składni; składni wykraczającej poza granice wypowiedzenia. Jest to składnia pozycji, współwystępowania, jak nazywa ją Jadwiga Wajszczuk 
(1997, 2005: 108), autorka najogólniejszego obrazu właściwości syntagmatycznych jednostek języka. Sformułowana przez J. Wajszczuk koncepcja opisu funkcjonalnego jednostek z perspektywy roli, jaką odgrywają one w wypowiedzeniu, jest rozwijana od 17 lat (Wajszczuk 1997, 2005). Aparat wypracowany na gruncie oryginalnej propozycji teoretycznej znalazł zastosowanie w pracach wielu badaczy. Odwołują się do niego choćby autorzy SGPP. Koncepcja ta stanowi także punkt odniesienia dla wnikliwego i pionierskiego opisu wyrażeń eksklamatywnych autorstwa Magdaleny Danielewiczowej (2014).

Przypomnę krótko zasadnicze zręby dystynkcji wskazywanych na gruncie składni pozycji. Wyodrębniane są jednostki, które nie wchodzą w relacje w składni zależnościowej. Brak łączliwości właściwy jest jednostkom nieustrukturyzowanym: apelom, wykrzyknikom, elementom fatycznym. W kolejnym kroku oddzielane są jednostki wchodzące w składnię zależności od elementów zestawionych z innymi na zasadzie współwystępowania - kookurencji. Te ostatnie to parataktemy lub inaczej operatory metatekstowe. Ich specyfiką jest otwieranie pozycji nienacechowanych gramatycznie. Służą one do komentowania w sposób zleksykalizowany (są to jednostki języka, nie konstrukcje, które skądinąd mogą pełnić analogiczną funkcję) poszczególnych poziomów struktury wypowiedzi, a więc: elementów zdania, całych zdań bądź składników wypowiedzenia (poszczególnych tematów lub rematów).

Zdaniem J. Wajszczuk lingwistyczny opis tej grupy wyrażeń powinien zawierać wskazanie odniesienia poszczególnych metaoperatorów, tj. płaszczyzn, na których pracują.

Płaszczyzną właściwą elementom stanowiącym przedmiot mojego zainteresowania jest sfera, jak nazywa ją J. Wajszczuk, „obróbki wypowiedzi” (Wajszczuk 2005: 104). Wielokropek i odpowiadająca mu intonacja to elementy kodu pozostające poza składnią zależności. W tym sensie, choć nie mają natury segmentalnej, należą do klasy parataktemów. O ich zaangażowaniu w płaszczyznę wypowiedzenia świadczy wymóg jednorodności tematu głównego narzucany odbiorcy przez nadawcę wypowiedzi z wielokropkiem lub intonacją otwartą. Wielokropek jest zatem operatorem perspektywy dialogicznej. Powiązanie wypowiedzi zawierającej wielokropek z kontekstem słownym i pozasłownym dostrzegała już wcześniej Iskra Angełowa (1982). Brak precyzyjnych narzędzi opisu uniemożliwiał autorce dokonanie bardziej szczegółowej charakterystyki funkcji wielokropka, tj. wskazanie tego, co i przez kogo powinno zostać uzupełnione.

$\mathrm{W}$ artykule prócz próby określenia funkcji wielokropka przedmiotem analizy będzie również użycie tego znaku w poezji B. Leśmiana. Jego zastosowanie w utworach poety jest przemyślane. Służy aktywizowaniu odbiorcy przy określonych wątkach poetyckich (por. pkt. 3). 


\section{Wielokropek w języku ogólnym}

Znak wielokropka w obiegu językowym pojawił się stosunkowo późno (por. SIJP: 14). Zazwyczaj językoznawcy wymieniają kilka jego funkcji. Według Stanisława Jodłowskiego (2002: 91) ${ }^{1}$ są trzy takie funkcje: przerwanie, opuszczenie lub niespodzianka. W Uwagach ogólnych SIJP (s. 14) wielokropek opisuje się podobnie. Znak ten sygnalizuje przerwę w wypowiedzi, „wskazuje na opuszczenie części wypowiedzi” oraz służy do „wskazywania na ładunek emocjonalno-logiczny” wypowiedzi. W Poradniku interpunkcyjnym pod red. Edwarda Polańskiego, Marka Szopy i Ewy Dereń znajdujemy bardziej rozbudowany komentarz na temat zastosowania wielokropka: „Wielokropek może się pojawić kilka razy w zdaniu, sugeruje on wtedy, że wypowiedź nie jest spójna i wynika ze zdezorientowania lub zdenerwowania mówiącego” (Polański, Szopa, Dereń 2010: 141). Dalej autorzy piszą: „[znak ten] służy także do zawieszenia głosu, aby wprowadzić treści nieoczekiwane przez czytelnika, tzn. rozczarowanie, ironię lub dowcip, i aby osłabić podniosły nastrój” (ibid.). W Poradniku... znajdziemy ostrzeżenie, by nie mylić wielokropka z wykropkowaniem, tj. pominięciem części wyrazów ze względu na tabu obyczajowe. Wśród funkcji wielokropka Poradnik... wymienia także zaznaczanie pauz oddających proces przypominania sobie lub jąkania się.

Funkcją wielokropka w literaturze i języku potocznym zajmowała się bliżej I. Angełowa $(1982,1985)$. Opisując właściwości tego znaku interpunkcyjnego, językoznawczyni podkreśla jego szerokie zastosowanie. Wielokropek pełni zarazem funkcję składniową (segmentującą), jak i semantyczną. Jest także znakiem redaktorskim.

Angełowa charakteryzuje wielokropek ze względu na jego relację do kontekstu zawierającego informację uzupełniającą wypowiedzenie $\mathrm{z}$ wielokropkiem. Badaczka zakłada, że wielokropek to sygnał niepełności informacyjnej. Twierdzi, że znak ten odsyła do informacji zawartej w kontekście słownym lub pozasłownym. Jej zdaniem informacja, do której odwołuje się wielokropek, częściej zawarta jest w kontekście poprzedzającym ten znak niż w następującym po nim zdaniu. Dzieje się tak zarówno w tekście prozatorskim, jak i rozmowach telefonicznych. Bywa jednak i tak, że wielokropek odwołuje się do wiedzy spoza kontekstu werbalnego.

Szerszy ogląd zastosowania wielokropka prezentuje również praca Edwarda Łuczyńskiego (1999). Autor zbiera liczne zastosowania tego znaku. Tak jak w poprzednich opracowaniach wyraźnie oddziela znak o funkcji semantycznej od technicznego wykropkowania. Wśród interpretacji funkcji wielokropka E. Łuczyński (ibid.: 165-169) wymienia „sygnalizowanie miejsca w tekście o szczególnym znaczeniu”, „wzmacnianie kropki”, „urwanie tekstu”, „pauzę”, „niespodziewaną informację".

1 Stanisław Jodłowski (2002: 22-23) podkreśla logiczno-składniowy charakter polskiej interpunkcji, co jego zdaniem nie wyklucza funkcji recepcyjno-recytacyjnej znaków interpunkcyjnych, wskazywanej w starszych opracowaniach. 
Podsumowując, wielokropek w opracowaniach lingwistycznych widziany jest przede wszystkim jako element niejednoznaczny, sygnał stanu emocjonalnego nadawcy lub spójności wypowiedzi. Jest więc postrzegany raczej jako wykładnik cech pragmatycznych wypowiedzi, a nie systemowy nośnik informacji.

Wiele wskazuje na to, że z wielokropkiem (intonacją otwartą) wiąże się ściśle określona funkcja. Powtarza się ona systematycznie w różnych kontekstach. Regularna powtarzalność efektu poznawczego lub sprawczego przy obecności określonej formy jest przesłanką skłaniającą do wyodrębnienia osobnego bytu języka. Pozostaje zatem wskazać ową powtarzającą się funkcję wielokropka. Dotychczasowe opisy podają w wątpliwość jednoznaczność funkcji tego znaku przestankowego. Aby ustalić, o jaką funkcję miałoby chodzić w wypadku tego znaku oraz czy jest ona regularnie powtarzalna, przyjrzyjmy się następującym kontekstom²:

(a) Nie należy również zapominać, że liczba siedem w Biblii to pełnia, doskonałość... (Świderkówna 1999: 47).

(b) Człowiek zaś niewierzący woli po prostu czytać i dać się porwać poezji tej Księgi, niźli studiować jej zawiłości filologiczne, chyba że... przypadkiem sam jest filologiem (ibid.: 135).

(c) Nie dziwimy się wcale, że mieszkańcy Jabesz nie chcieli przyjąć takiej propozycji, my jednak nie mówilibyśmy tutaj o „przymierzu”... (ibid.: 164).

(d) Wszystko się skończyło... (ibid.: 179).

(e) Może ich też to czeka? Przy kratach zwisa gruba lina... (Fabiani 2013: 20).

(f) $[\ldots]^{3} \mathrm{w}$ tym samym czasie nadjechał z Mantui... Giovanni Baglione (ibid.: 32).

(g) Nie pragnę pozostawać w Neapolu, nie mam chęci już tu mieszkać... - napisała (ibid.: 48).

(h) Lepiej się czuł wśród ludzi prostych, a najlepiej wśród... graczy w karty (ibid.: 64).

(i) Po konserwacji obrazu ojca widać wyraźnie, że Chrystus ma... dwie głowy (ibid.: 99).

Wypowiedzenia zawierające celowo użyty ${ }^{4}$ wielokropek dzielą się na trzy typy. Po pierwsze, wielokropek występuje na końcu frazy zawierającej wyliczenie, jak w przykładzie (a). Po drugie, wielokropek może pojawić się na końcu zdania bez wy-

2 Przyjmuję, że wszystkie wymienione konteksty mogą zostać wypowiedziane w intonacji otwartej.

3 Znak skrótu w cytacie [...] nie stanowi przedmiotu mojego namysłu. W cytatach wielokropek realizujący interesującą mnie funkcję zaznaczam pogrubieniem.

4 Sytuacja oznaczania wielokropkiem niepłynności wypowiedzi w sposób fundamentalny różni się od analizowanych przeze mnie wypowiedzeń, gdzie wielokropek jest zamierzony. Znak ten i odpowiadające mu brzmienie sygnalizują operację mówiącego na strukturze informacyjnej wypowiedzenia. 
liczenia, przy tym składniowo pełnego (przykłady (c) i (d)). Po trzecie, wielokropek pojawia się w środku wypowiedzenia. Ostateczne zamknięcie składniowe rozważanych kontekstów przeczy możliwości interpretowania występującego w nich wielokropka jako „opuszczenia części wypowiedzi” (por. SIJP: 14). Wszystkie wypowiedzi (a)-(i) są pełne informacyjnie.

Konteksty (a)-(i) nie wykluczają charakterystyki podanej w SIJP, mianowicie „wskazywania na ładunek emocjonalno-logiczny” (ibid.). Kłopotliwy jest stopień ogólności tego sformułowania. W gruncie rzeczy opis ten odpowiada właściwościom dowolnego znaku przestankowego i licznych jednostek segmentalnych. Z kolei obserwacja S. Jodłowskiego o niespodziance wprowadzanej za pomocą wielokropka pasuje do kontekstów, w których wielokropek użyty jest w środku wypowiedzenia. Jednak nadawca wcale nie musi kontynuować wypowiedzi zakończonej wielokropkiem. Na przykład wypowiedzenie: Wszystko się skończyło... nie stwarza efektu niespodzianki. Trudno tu doszukać się opuszczenia jakiejś określonej informacji lub przerwania wypowiedzi - kontynuacja po wielokropku w tym wypadku wcale nie jest konieczna.

Ułatwieniem we wskazaniu funkcji wielokropka jest skontrastowanie jego użycia z innymi elementami kodu. Wielokropek (poza niektórymi kontekstami poetyckimi i w odróżnieniu od myślnika) zawsze związany jest z określonym wypowiedzeniem. Jest to jednostka wymagająca w swoim kontekście pełnej struktury tematyczno-rematycznej (tego, o czym się mówi, i tego, co jest o tym czymś powiedziane). Jednocześnie użycie wielokropka wyłącza wypowiedzenie stanowiące jego operandum z porządku przedmiotowego (czego nie czynią spójniki) w tym sensie, że wypowiedzenie takie traci możliwość stania się przedmiotem sprawozdania w mowie zależnej. Chcąc w adekwatny sposób zdać sprawę z wypowiedzenia (d), musimy użyć przytoczenia:

+Powiedział: wszystko się skończyło...

W przeciwnym razie wielokropek i to, co ze sobą wnosi, obejmuje wypowiedzenie sprawozdawcze, a nie fragment będący przedmiotem sprawozdania. Autorem niedopowiedzenia staje się nadawca zdania sprawozdawczego, por.:

Powiedział, że wszystko się skończyło...

Użycie wielokropka, jak słusznie podkreślano w wielu pracach, tworzy wyłom w dotychczasowym toku mówienia. Natomiast wbrew licznym zapisom w opraco-

5 Rolę predykatu powiedzieć, że w wyznaczaniu wypowiedzi bazowych (przedmiotowych) podkreśla Andrzej Bogusławski (2008: 27-43). W nowszych pracach (np. Bogusławski 2017: 42), uściślając swoje wcześniejsze propozycje, badacz dodaje, że czasownik służący odróżnianiu wypowiedzeń bazowych od nieliteralnych i egocentrycznych musi wystąpić pod niekontrastywnym akcentem frazowym. 
waniach interpunkcji wielokropek nie zdradza stanu emocjonalnego nadawcy ani jego oceny tego, o czym mowa. Jednostka ta nie wyklucza ani pozytywnej, ani negatywnej oceny tego, o czym mowa. Można powiedzieć zarówno: +Nareszcie wszystko się skończyło..., jak i: +Niestety, wszystko się skończyło...

Pod groźbą efektu sprzecznościowego wielokropek przesądza o możliwości powiedzenia czegoś więcej.

Zdanie:

* O liczbie siedem w Biblii powiem wszystko, co można, jest to pełnia, doskonałość...

nie jest poprawnie zbudowane - skoro nie można o liczbie siedem powiedzieć nic więcej, w miejscu wielokropka powinna pojawić się kropka.

Wielokropek służy zaznaczeniu miejsca, w którym mówiący przekazuje głos odbiorcy. To odróżnia go od przecinka i pauzy. Pozycja wielokropka określa temat (T) i aspekt tematyczny (TQ) ${ }^{6}$ (termin wprowadzony przez J. Wajszczuk 1997: 238-242) wypowiedzi oczekiwanej przez nadawcę. W wypadku przywołanych zdań będą to np.:

Ad (a) T: liczba siedem; TQ: Czym jest?

Ad (b) T: koncesywność studiowania zawiłości filologicznych Biblii; TQ: Jaka jest? / Jaki to warunek?

Ad (c) T: nazywanie propozycji Boga dla mieszkańców Jabesz; TQ: Jak ją określić?

Wielokropek stanowiący apel do adresata o powiedzenie czegoś więcej na wskazany temat wbrew sugestii E. Łuczyńskiego (1999: 166) nie wzmacnia kropki, ale z nią konkuruje. Kropka nie mówi nic o roli adresata w związku z przekazaną askrypcją (o asercyjnej funkcji kropki w wypowiedzi por. Bogusławski 1998: 22, 2007: 70). Pozostaje także w opozycji względem średnika i przecinka (o ile ten oddziela całość informacyjną). Oba te elementy mające swoje odpowiedniki wymawianiowe nie dopuszczają adresata do głosu.

Wydawać by się mogło, że wielokropek wyklucza również pytajnik. Są jednak rzadkie konteksty, w których oba te znaki i związane z nimi funkcje współwystępują, obejmując to samo wypowiedzenie:

6 J. Wajszczuk identyfikuje aspekt tematyczny (TQ) z określoną sferą semantyczną, ze względu na którą następuje wybór rematów w wypowiedzeniu. Jest to, jak pisze językoznawczyni, „obowiązkowa charakterystyka tematu wyznaczająca zakres kategorialny wyrażeń rematycznych tego samego piętra" (Wajszczuk 1997: 239). 
A gdyby?... (Świderkówna 1999: 66).

Ale czyż Bóg może kogoś szukać nadaremnie?... (ibid.: 246).

Pytanie (o typach i funkcji pytań por. Danielewiczowa 1996, zwł. 37-43; o ogólnej interpretacji presupozycji członu pytajnego zdania złożonego por. Bogusławski 1979: 34) i wielokropek oddają głos adresatowi, określając ściśle temat i aspekt tematyczny repliki ${ }^{7}$. Pytanie właściwe jako typ aktu mowy wymaga odpowiedzi zakładanej przez pytającego i dostępnej mu.

Tymczasem używając wielokropka, mówiący nie oczekuje dostępu do wiedzy adresata. Adresat ma skonfrontować się z własną wiedzą o temacie wypowiedzi, ma uświadomić sobie rzecz zarysowaną w wypowiedzeniu mówiącego. Ma to być pokaz wiedzy dokonany „na własne potrzeby”, nie na potrzeby nadawcy. Występując po pytajniku w tekście pisanym, wielokropek sygnalizuje „prywatny” charakter repliki. W ten sposób uzupełnia funkcję pytajnika, utrzymując powagę jego wymagań w oderwaniu wypowiedzi od bezpośredniej obecności autora, charakterystycznym dla pisma.

Podsumowując, możemy stwierdzić, że regularną funkcją wielokropka jest przekazanie głosu adresatowi oraz apel, wiążący się z oczekiwaniem określonego działania mownego odbiorcy. Nadawca wskazuje temat i aspekt tematyczny, które stanowią inspirację do niewyrażanej głośno wypowiedzi adresata. W tym sensie intuicja I. Angełowej (1982) o powiązaniu zdań z wielokropkiem z innymi wypowiedzeniami jest słuszna. Wypowiedzenie z wielokropkiem nie może istnieć w próżni.

\section{Wielokropek w twórczości Bolesława Leśmiana. Forma, statystyka i powinowactwa}

Przy czysto zewnętrznym oglądzie (nawet nie lekturze) wierszy autora Dziejby leśnej zwraca uwagę pewien drobiazg - powtarzający się w nich wielokropek. Drobiazg do dziś niedostrzegany i niepoddany interpretacji krytycznoliterackiej. A przecież jedynie nieliczne utwory Leśmiana pozbawione są tego znaku. Tylko w pierwszych 40 utworach Sadu rozstajnego wielokropek pojawia się 106 razy. Daje to częstotliwość ponad 2 znaków na utwór.

Wydobycie funkcji wielokropka w języku ogólnym jest dla mnie punktem wyjścia do analizy wierszy B. Leśmiana. Ponieważ funkcja niedopowiedzenia/wielokropka nie zmieniła się znacząco na przestrzeni dziesiątków lat, krok ten mimo

7 Istoty zdań pytajnych (w tym wypowiedzeń z członem wprowadzanym za pomocą zaimka pytajnego) oboje autorzy upatrują w wyrażaniu chęci mówiącego do „bycia skonfrontowanym z prawdziwymi zdaniami oznaczającymi ekwiwalentną relację między pewnymi pojęciowymi przedmiotami a specyficznymi deskrypcjami zawartymi w datum quaestionis" (Bogusławski 1979: 34; Danielewiczowa 1996: 39). 
formalnej anachroniczności daje się obronić w perspektywie funkcjonalnej. Mam poczucie, że skupienie uwagi na świadomym operowaniu niedopowiedzeniem przez B. Leśmiana może stanowić jeden z kluczy interpretacyjnych do jego poezji. Jednocześnie kontrast między kodową funkcją niedopowiedzenia czy, jak je nazywam, współ-powiedzenia a jego poetyckim użyciem uwyraźnia rolę wielokropka w codziennym dyskursie.

Biorąc pod uwagę wysoką frekwencję tego środka, niepojawiającego się z taką częstotliwością u poetów następnego pokolenia ceniących autora Łąki, jak Julian Tuwim czy Kazimierz Wierzyński, dziwi brak próby ustalenia funkcji tego znaku w twórczości piewcy potęgi natury. Dziwi tym bardziej, że jak podkreśla wydawca Poezji zebranych Jacek Trznadel, Leśmian dbał o zapis i stronę edytorską utworów:

Mamy jednak prawo sądzić, że Leśmian używał interpunkcji w swoich utworach świadomie. Czynił różne odstępstwa od obowiązujących dziś norm i w niektórych zastosowaniach, jak sądzę, powinniśmy jego interpunkcję zachować (Trznadel 2010: 682).

I dalej, równie ostro: „Zmieniać czy ujednolicać interpunkcję Leśmiana to naruszyć być może autorską interpretację tekstu"s.

Bez wątpienia wielokropek obok pauzy jest znakiem rozpoznawczym poezji Leśmiana. Niewykluczone, że nie mniej istotnym od jego zabiegów słowotwórczych, rytmicznych czy wreszcie wyboru tematyki.

Podkreślić trzeba jednak, że to nie Leśmian jest pomysłodawcą wyjątkowo obfitego zastosowania wielokropka (także pauzy) w poezji. Chwyt ten przejął poeta od swojego mistrza - Miriama. Uderzająca jest analogia frekwencji tych znaków u obu poetów. W porównywalnej próbie 40 wierszy (tyle zawierał tomik $Z$ czary młodości Zenona Przesmyckiego (1893)) z pierwszych wydanych przez nich tomików wypadają średnio 2 wielokropki i 5 pauz na utwór, przy czym u Leśmiana wielokropek jest nieco częstszy niż u Przesmyckiego (106 do 81). Oczywiście poprzestawanie na samej formie znaku bez analizy i porównania jego funkcji byłoby rażącym uproszczeniem. Dlatego chciałabym choć w niewielkim wymiarze podjąć się próby interpretacji tej specyficznej jednostki języka, pozostawiając znawcom poszukiwania dalszych inspiracji (np. norwidowskich).

Użycie wielokropka przez Leśmiana nie jest jedynie manierą młodopolską przejętą od mistrza. Nie wszystkie utwory go zawierają. Brak go w Balladach i Pieśniach kalekujacych; powraca (w tym samym tomiku) w cyklu Łąka; jest obecny w Powieści o rozumnej dziewczynie i w Dziejbie leśnej. Twierdzenie J. Trznadla, że: „Interpunkcja Leśmiana w zasadzie nie zmienia się od pierwszego do ostatniego wydanego za

8 A jednak wydawca wprowadził delikatny retusz: gdy po przecinku następował znak pauzy - likwidował przecinek. Gdy pauza poprzedzała cudzysłów, likwidował pauzę. Wielokropek na tych zabiegach szczęśliwie nie ucierpiał. 
jego życia zbioru poezji” (Trznadel 2010: 682), w odniesieniu do wielokropka trzeba doprecyzować. Omawiany znak przestankowy jest w poezji autora Sadu rozstajnego obecny do końca, ale nie stale. Jego użycie podyktowane jest gatunkiem i sytuacją liryczną utworu. Najogólniej obecność wielokropka wiązałabym z przekraczaniem granicy mowy i rzeczywistości w kontakcie z kimś bliskim.

\section{Wielokropek w wierszach Bolesława Leśmiana}

Jak wspomniałam, wielokropek jest jednym z częstszych środków interpunkcyjnych wykorzystywanych przez Leśmiana. Czemu ma służyć? Co decyduje o jego użyciu bądź nieobecności w utworze?

\subsection{Granica ja - ty}

Ogląd utworów, w których brak wielokropka, odsłania pierwszą z jego funkcji. Poeta używa tego środka tam, gdzie podmiot liryczny wchodzi w dialog z kimś sobie bliskim, do kogo może poprzez wykorzystanie wielokropka powiedzieć: Wiesz, o czym mówię. Na obecność tego odwołania jako swoistej stałej semantycznej zwraca uwage Andrzej Bogusławski (2018). Ów element pojęciowy jest obecny także w strukturze semantycznej wybranych jednostek językowych. Wśród nich znajdzie się również wielokropek, jeśli zgodzimy się, że jest on elementem kodu.

Wielokropka nie znajdziemy w Balladach (dedykowanych Miriamowi) ani Pieśniach kalekujących, gdyż jak pokazał Eugeniusz Czaplejewicz (1973), mamy w nich do czynienia $\mathrm{z}$ adresatem zbiorowym - gromadą, uczestniczącą biernie w opowieści śpiewaka. Wielokropek pojawia się za to $\mathrm{w}$ dialogach miłosnych, dialogach $\mathrm{z}$ kimś bliskim, z kimś, kto sprawia, że podmiot zatraca granice swojego ,ja”. Znajdziemy go zatem w wierszach opisujących taką właśnie sytuację. Będą to: Nocą umówioną, Nad ranem, a także cykl Łąka (nawiązujący do Pieśni nad Pieśniami). Co ciekawe, cykl ten następuje po pozbawionych wielokropka Balladach i Pieśniach kalekujących.

$\mathrm{W}$ kontekście rozważań o roli wielokropka $\mathrm{w}$ poezji Leśmiana znamienny jest jego brak w wierszu o incipicie Dziś w naszego spotkania rocznicę. Wiersz ten mówi o kryzysie, wyczerpaniu miłości i wymagającej wysiłku próbie powrotu.

Oczywiście użycie wielokropka nie ogranicza się do dialogów miłosnych. Szczególną rolę niedopowiedzenie odgrywa na początku Nieznanej podróży Sindbada-Żeglarza. Utwór ten rozpoczyna, przypomnę, inicjalna pozycja wielokropka. Jest ona wykluczona w języku niepoetyckim. Narracja wprowadzona w tym utworze jest odpowiedzią bohatera na zadane, ale niewypowiedziane w tekście pytanie rozmówcy, który dzięki temu zabiegowi staje się aktywnym inicjatorem opowieści. 


\subsection{Granica tu - tam}

Obecność wielokropka jest charakterystyczna dla dialogu bliskich osób. Pojawia się on również tam, gdzie stykają się i mieszają Leśmianowskie „dwa światy”. Nie ma go w Balladach - dominuje tu bowiem rzeczywistość nieziemska, niezwyczajna. Tej rzeczywistości nie ma we wspomnianym już wierszu o incipicie Dziś w naszego spotkania rocznice, w którym znajdujemy się w zamkniętej przestrzeni domu. Wielokropek pojawia się w zbiorze Łąka. Powtarza się także w finale utworów z cyklu Aniołowie, a przede wszystkim w pięknym, „wielokropkowym” (w różnych wymiarach) Dniu skrzydlatym, w którym główny temat stanowi styk rzeczywistości boskiej i ludzkiej.

\subsection{Granica tak - nie}

Ostatnią omówioną w tym artykule funkcją wielokropka jest sygnalizowanie granicy wyrażalności. Napięcie między tak i nie, między możnością i niemożnością werbalizacji jest źródłem Leśmianowskich neologizmów. Wyraża się ono również poprzez wielokropek, zwłaszcza tam, gdzie pojawia się paradoks, sprzeczność, jak w wierszu Po ciemku:

Świat się trwali, ale tak niepewnie!...

Drzewa szumią, ale pozadrzewnie!...

[...]

Dwa po ciemku pałające ciała...

Podobny chwyt obserwujemy we wspomnianym już wierszu Nad ranem: „Polegniem - snem czynni...”; w Nocy: „Już płaczą rzeczy martwe...” czy w Klęsce: „I nie było tych godzin, gdym jeszcze nie zginął...”.

Po tym względem wyjątkowy jest wiersz Dwaj skazańcy, w którym napięcie między tak i nie, chce i nie chcę wprowadza nas w świat urojeń sygnalizowany przez wielokropek:

A drugi wnet zawołał: „Ja nie mam rodziny!”

A miał ją, lecz mieć nie chciał... Tak mu się zdawało.

Kolejne przykłady potwierdzają siłę poetyckiego rozdarcia między wykluczającymi się stanami:

Wiem ja wszystko! / Ale czemu łkam - / Tego nie wiem, nie pojmuję sam... (Tam na rzece...).

I powymarły jeszcze raz, bo nigdy dość się nie umiera... (Dziewczyna). 


\section{Konkluzja}

Wielokropek w poezji Leśmiana prócz zwykłej funkcji oddawania głosu adresatowi, apelu o dopowiedzenie sobie przez niego określonych treści i założenia wspólnej $\mathrm{z}$ odbiorcą wiedzy o temacie (i aspekcie tematycznym) wydobywa fundamentalną dla poezji Leśmiana transcendentalność trzech granic wyznaczanych przez opozycje: ja - ty, ten świat - zaświaty, tak - nie. Są to granice indywiduum, czasoprzestrzeni i mowy. Wszystkie trzy pojawiają się w przesyconym wielokropkami Dniu skrzydlatym:

Rozwidniły się w słońcu dwie otchłanie - dwa światy Myśmy byli - w obydwu... A dzień nastał skrzydlaty.

Nikt nie umarł w dniu owym - nie zataił się w cieniu... I pamiętam, żem myślał o najdalszym strumieniu.

Nie mówiłaś nic do mnie, lecz odgadłem twe słowa, A on - zjawił się nagle... Zaszumiała dąbrowa.

Taki - drobny i nikły... I miał - ciernie na skroni.

I uklękliśmy razem - w pierwszej z brzegu ustroni.

W pierwszej z brzegu ustroni - w pierwszej kwiatów powodzi.

I zdziwiło nas bardzo, że tak biednie przychodzi.

Ubożeliśmy chętnie - my i nasze zdziwienie...

A on - patrzał i patrzał... Cudaczniało istnienie...

Zrozumieliśmy wszystko! - I że właśnie tak trzeba!

I że można - bez szczęścia... I że można - bez nieba...

Tylko drobnieć i maleć od nadmiaru kochania.

A to była - odpowiedź, i nie było - pytania.

I już odtąd na zawsze przemilczeliśmy siebie,

A świat znów się stał - światem... I czas płynął po niebie.

I chwyciłaś źdźbło czasu, by potrzymać je - w dłoni, A on - patrzał i patrzał... I miał - ciernie na skroni. 


\section{Literatura}

AngeŁowA I., 1982, Charakterystyka wielokropka na tle pozostałych znaków interpunkcyjnych polszczyzny, „Język Polski” LXII, s. 158-166.

AngeŁowA I., 1985, Charakterystyka interpunkcji polskiej w świetle normy i praktyki, Wrocław.

BogusŁawski A., 1979, Indirect Questions. One Interpretation or More, „Linguistica Silesiana" 3, s. 39-52.

BogusŁawski A., 1998, Science as Linguistic Activity, Linguistics as Scientific Activity, Warszawa.

BogusŁaWski A., 2007, A Study in the Linguistic-Philosophy Interface, Warszawa.

BogusŁawski A., 2008, Semantyka, pragmatyka. Leksykografa głos demarkacyjny, Warszawa.

BogusŁaWski A., 2017, W sprawie językowo-autorefleksyjnego testowania wymagań składniowych, „Prace Filologiczne” LXX, s. 33-45.

BogusŁawski A., 2018, Do kwestii „stałych lingwistycznych”. Czy „stała interpretacyjna” 'wiesz o czym mówię??, „Linguistica Copernicana” 15, s. 27-36, [on-line:] http://dx.doi. org/10.12775/LinCop.2018.003.

Czaplejewicz E., 1973, Adresat w poezji Leśmiana, Wrocław.

DANiElewiCzowa M., 1996, O znaczeniu zdań pytajnych w języku polskim. Charakterystyka struktury tematyczno-rematycznej wypowiedzeń interrogatywnych, Warszawa.

Danielewiczowa M., 2014, Struktura i znaczenie eksklamatywów. Na materiale współczesnej polszczyzny, Warszawa.

FABIANi B., 2013, Dalsze gawędy o sztuce: XVII wiek, Warszawa.

JodŁowski S., 2002, Zasady interpunkcji. Podręcznik, oprac. nauk. i red. J. Godyń, wyd. nowe zm. i rozsz., Kraków.

ŁUCZyŃski E., 1999, Współczesna interpunkcja polska. Norma a uzus, Gdańsk.

Polański E., Szopa M., Dereń E., 2010, Poradnik interpunkcyjny, Katowice.

Przesmycki Z., 1893, Z czary młodości: liryczny pamiętnik duszy, Wiedeń - Kraków, [on-line:] http://kpbc.umk.pl/dlibra/docmetadata?id=14306\&from=publication.

SGPP: M. Grochowski, A. Kisiel, M. Żabowska, Słownik gniazdowy partykuł polskich, Kraków 2014.

SIJP: J. Podracki, Słownik interpunkcyjny języka polskiego z zasadami przestankowania, Warszawa 1996.

Świderkówna A., 1999, Rozmowy o Biblii, Warszawa.

Trznadel J., 2010, Zasady wydania, [w:] B. Leśmian, Poezje zebrane, oprac. J. Trznadel, Warszawa, s. 681-688.

WAjszczuk J., 1997, System znaczeń w obszarze spójników polskich. Wprowadzenie do opisu, Warszawa.

WAjSzczUK J., 2005, O metatekście, Warszawa.

ZAUCHA J., 2015, Jak brzmi niedopowiedzenie? Prozodyczna jednostka właczenia $w$ dialog rekonesans, [w:] M. Danielewiczowa, J. Bilińska, K. Doboszyńska-Markiewicz, J. Zaucha (red.), Sens i brzmienie, Warszawa, s. 65-85. 


\section{Co-saying. On the Function of Ellipsis in General Polish, and in Bolesław Leśmian's Poetry Summary}

The goal of the paper is to identify the function of ellipsis in general Polish, and in Bolesław Leśmian's poetry. This author assumes that ellipsis corresponds to a specific intonation, has a code character, and belongs to the group of dialogic perspective operators (cf. Wajszczuk 2005). Its function is simply an appeal to the addressee, to complete the utterance with specific content by themselves. The unit is used creatively by Bolesław Leśmian. In his poetry, co-saying serves to express the transcendence of three boundaries set by the oppositions $I$ : you, here: there, yes : no. 